\title{
Kriminalitetsprofiler i en dansk retspsykiatrisk population - udfordringer for psykiatriens kriminalitetsforebyggende opgave? ${ }^{1}$
}

\author{
Af Liv Os Stølan, ${ }^{2}$ Hans Raben, ${ }^{3}$ Lis Sørensen, ${ }^{4}$ \\ Mette Brandt-Christensen ${ }^{5}$ og Jette Møllerhøj ${ }^{6}$
}

\begin{abstract}
The aim of the study is to identify and describe a number of characteristics among a selected sample of mentally disordered offenders referred to a specialized forensic assertive community treatment team in Copenhagen $(n=181)$. Looking at a number of variables, the study identifies a heavily burdened patient population in terms of social marginalization, serious mental illness, and criminal acts. Having identified a huge variety and number of typologies of criminal acts, we argue that the task of preventing recidivism to new crime not clear among mental health professionals. Furthermore, it proves difficult to prevent crime when the typologies of crime are diverse and widespread. It is one thing is to prevent violent crimes closely related to an actual psychotic mental state and quite another to prevent drug crimes or property crimes not so obviously related to a mental disorder. The article concludes that we need to increase our knowledge and awareness of risk and protective factors specifically related to criminal recidivism and improve cooperation between hospital psychiatry, social services and probation services.
\end{abstract}

\section{Baggrund}

I Danmark er der over de sidste årti set en tredobling i antallet af retspsykiatriske patienter, fra 1445 unikke patienter i 2001, til 4393 patienter i 2014. ${ }^{7}$ Dette er personer, der er kendt skyldige $i$ at have begået kriminalitet $i$ henhold til straffeloven, men som af domstolen er kendt straffrie på grund af »sindssygdom eller tilstande, der må ligestilles hermed «, ${ }^{8}$ og er idømt en psykiatrisk særforanstaltning. Formålet med den psykiatriske særforanstaltning er, at den »findes formålstjenlig for at forebygge yderligere lovovertrædelser. ${ }^{9}$ Det kriminalitetsforebyg-

* Title in English: Typologies of crime committed by mentally disordered offenders: A challenge to the statutory task in hospital psychiatry of preventing recidivism to criminal acts. 
gende element er altså udtalt i lovteksten, og det behandlingsmæssige ansvar for varetagelsen af den idømte behandling påhviler den regionale hospitalspsykiatri, ${ }^{10}$ ofte med tilsyn fra Kriminalforsorgen.

At forebygge handler om at begrænse forekomsten af et problem, eller hindre at det opstår. Kriminalitet kan sjældent forklares eller forstås i et direkte årsags/virkningsperspektiv, men må anskues som et samspil af multikomplekse og multifaktorelle processer, hvor en række risikofaktorer og beskyttende faktorer indgår. ${ }^{11}$ Kriminalitetsforebyggelse er generelt en kompleks og mangefacetteret opgave, der kræver en bred indsats på mange niveauer, og sammenhængen mellem risikofaktorer og kriminalitet er velkendt. ${ }^{12}$ Det er ikke givet eller forudsigeligt, hvorledes risikofaktorer og beskyttende faktorer interagerer i det enkelte individs liv. For enkelte er alvorlig psykisk sygdom en komplicerende tillægsfaktor, og alvorlig psykisk sygdom (i det skizofrene spektrum) anses som en risikofaktor for at begå personfarlig kriminalitet. ${ }^{13}$ Der er behov for mere viden om hvilke yderligere risikofaktorer, der indgår i patienternes liv, udover alvorlig psykisk sygdom. Derudover savnes mere viden om patienternes samlede kriminalitetshistorik og de eventulle udfordringer, dette kan medføre for det kriminalitetsforebyggende sigte med den psykiatriske særforanstaltning. ${ }^{14}$

\section{Formål}

Formålet med denne undersøgelse og analyse er at beskrive den diversitet og kompleksitet, der kendetegner en afgrænset, særlig belastet del af den retspsykiatriske population, både med hensyn til det, der karakteriseres som risikofaktorer i forhold til at begå kriminalitet, og denne populations kriminalitets- og psykiatriske historik. ${ }^{15}$ Med afsæt $\mathrm{i}$ en analyse af den enkelte patients samlede kriminalitetsomfang beskrives tre forskellige kriminalitetsprofiler, der gør sig gældende i populationen, og hvad der kendetegner profilernes sociodemografiske karakteristika, kriminalitetshistorik og kontakt med psykiatrien.

I artiklens anden del diskuterer vi, hvorledes denne diversitet kan være en udfordring, når psykiatrien skal løfte ansvaret for at forebygge ny kriminalitet. Vi peger afslutningsvis på, at det kræver en fleksibel og mangefacetteret tilgang og indsats for at indfri formålet med en psykiatrisk særforanstaltning.

Det er en grundlæggende antagelse for studiet, at viden om den enkeltes livssituation, eventuelle tidligere kriminalitetserfaringer og kontakt med det psykiatriske system er en forudsætning for en adækvat kriminalitetsforebyggende indsats. Datamaterialets detaljeringsgrad giver os en mulighed for en bredere viden om denne særlige, belastede del af den retspsykiatriske population. Vi håber, at undersøgelsen kan være hypotesegenererende og bidrage til yderligere forståelse af 
det komplekse samspil mellem psykisk sygdom og forebyggelse af kriminalitet, også for den retspsykiatriske population som helhed.

\section{Materiale og metode}

Undersøgelsen baseres på journalmaterialet ${ }^{16}$ vedrørende patienter, der er behandlet $i$ et specialiseret retspsykiatrisk opsøgende team ${ }^{17}$ i Region Hovedstadens Psykiatri over en periode på $71 / 2$ år ${ }^{18}$ og i de aktuelle analyser indgår 172 af i alt 181 patientforløb. ${ }^{19}$ Hovedformålet med undersøgelsen er at beskrive udvalgte karakteristika (psykiatriske, retslige, demografiske og sociale forhold) for gruppen af patienter behandlet i dette team. Datagrundlaget er oplysninger, der foreligger i den enkelte patientjournal, herunder domsudskrifter (indeksdom, ${ }^{20}$ eventuelle tidligere domme og eventuelt nye domme i behandlingsforløbet), mentalerklæringer m.m. Et omfattende registreringsskema er udfyldt for hvert patientfor$1 ø b^{21}$ og favner en bred vifte af variable vedrørende patientens demografiske baggrund og aktuelle situation, den eventuelle psykiatriske og retslige historik, herunder antal pådømte forhold i hver lovbrudskategori samt udvalgte kliniske variable knyttet til behandlingsforløbet. ${ }^{22}$ Data er anonymiseret og elektronisk lagret. De statistiske analyser er foretaget ved SAS 9,3. ${ }^{23}$

Patienterne, der behandles i det specialiserede opsøgende team, er blandt de mest belastede retspsykiatriske patienter, og de henvises dertil på baggrund af en eller typisk flere problemstillinger, der gør patienterne svære at rumme i de almenpsykiatriske ambulante tilbud. Mange har været idømt en anbringelsesdom og har været indlagt i en årrække, før dommen er ændret til en behandlingsdom med mulighed for ambulant behandling. ${ }^{24}$

Der er store forskelle og stor bredde i patientgruppens kriminalitetsbelastning, og i denne artikel fokuserer vi på beskrivelser og analyser af de forskellige kriminalitetsprofiler, der gør sig gældende i populationen, opdelt efter hvor kriminalitetsaktive de har været i deres samlede kriminelle karriere. ${ }^{25}$ Ved afsæt i alder for kriminel debut og deres alder ved indeksdom har vi beregnet den samlede tid $\mathrm{i}$ år, den enkelte patient har været kriminalitetsaktiv. Med afsæt i længden af deres kriminelle løbebane indtil indeksdom og deres samlede antal pådømte kriminelle forhold er den enkelte patients gennemsnitlige antal forhold pr. år beregnet. Med udgangspunkt i omfanget af pådømte forhold, uafhængig af kriminalitetstype, ses tre forskellige profiler:

- Debutanterne $(\mathrm{n}=32)$ : er ikke tidligere dømt for kriminalitet.

- Lejlighedsvis kriminel/mellemprofil $(\mathrm{n}=69)$ : er i gennemsnit dømt for mindre end et kriminelt forhold pr. år siden kriminel debut. 
- De tungt kriminalitetsbelastede/tung profil $(\mathrm{n}=71)$ : er i gennemsnit dømt for minimum et forhold pr. år siden kriminel debut.

På det deskriptive niveau og med afsæt i omfanget af kriminalitet, er der væsentlige forskelle mellem profilerne på en række parametre, også med hensyn til kriminalitetskategorier og lovbrudstyper. Statistiske analyser foretaget ved en multinominal logistisk regression bekræfter, at der er forskelle mellem grupperne.

\section{Sociodemografi}

Sociodemografiske forhold: marginaliserede positioner

Patienterne, der behandles i det specialiserede opsøgende team, er henvist dertil på baggrund af en eller typisk flere problemstillinger, der gør patienterne svære at rumme i de almenpsykiatriske tilbud. De er oftest dømt for personfarlig kriminalitet; de kan have en aggressiv og truende adfærd; de har typisk et væsentligt brug af rusmidler. Problemkompleksiteten er ofte omfattende og patienterne er blandt de mest belastede retspsykiatriske patienter. De fleste i populationen er mænd (96 \%). Mange er i, og har længe været i, svært socialt marginaliserede positioner:

Opvaekstforhold: Mange har været anbragt udenfor hjemmet i løbet af opvæksten, men der er store forskelle mellem profilerne: Næsten 5 af 10 (46,5\%) med tung profil har været anbragt i en socialpædagogisk institution eller i plejefamilie, før de fyldte 18 år som følge af forholdene i opvæksthjemmet (pga. vanrøgt, overgreb m.v.). Dette gælder 3 af 10 af de med en mellemprofil, og 1 af 10 af debutanterne $(p=0,004)$. En statistisk analyse foretaget ved en logistisk regression viser, at sandsynligheden for at en patient med en tung kriminalitetsprofil har været anbragt udenfor hjemmet, er næsten 7 gange større $(\mathrm{OR}=6,78)$ end for en patient blandt debutanterne. ${ }^{26}$

Mange har ikke gennemført det obligatoriske grundskoleforløb og de fleste modtager offentlig forsørgelse: 8 af 10 af debutanterne har gennemført det i Danmark obligatoriske grundskoleforløb. Det samme har 7 af 10 fra mellemgruppen, mens det kun gælder 5 af 10 af de med en tung profil $(p=0,003)$. Samlet er det kun 2 af 10 der har en afsluttet eksamen/uddannelse $u d$ over grundskoleeksamen. 9 af 10 modtager offentlig forsørgelse (førtidspension eller kontanthjælp). ${ }^{27}$

Mest kriminalitet - flest stoffer: Brug af euforiserende stoffer var udbredt i populationen på tidspunktet for indekskriminalitet, og kriminalitetsbelastning og stofbrug sammenfalder i høj grad: Mens flere end 7 af 10 af de mest kriminalitetsbelastede var brugere af et eller flere euforiserende stoffer på tidspunktet for indekskriminalitet, gælder det kun ca. 3 af 10 af debutanterne $(p=0,0001){ }^{28}$ 
Halvdelen har en etnisk minoritetsbaggrund: Samlet har 5 af 10 i populationen en etnisk minoritetsbaggrund, ${ }^{29}$ men de fleste af disse patienter har levet størstedelen af livet i Danmark. ${ }^{30}$ Fordelingen er ikke ens i de tre grupper: 6 af 10 med en tung profil har en etnisk minoritetsbaggrund, mens det gælder 4 af 10 i de to andre grupperinger $(p=0,092)$. Sandsynligheden er 5 gange større for at en patient med tung kriminalitetsprofil har en etnisk minoritetsbaggrund end en patient fra debutantgruppen $(\mathrm{OR}=5,16)$. Etnisk minoritetsbaggrund er også den faktor med størst betydning, når vi sammenligner de to profiler, der har tidligere kriminalitetserfaring: Der er 3 gange større sandsynlighed for, at en patient med en etnisk minoritetsbaggrund har en tung kriminalitetsprofil, end at patienten er i mellemgruppen $(\mathrm{OR}=2,91)$.

\section{Psykiatri: høj sygdomsgrad og mange psykiatriske kontakter}

Patienterne har samlet en udbredt erfaring med det psykiatriske behandlingssystem, hvilket afspejles i en udtalt sygdomsgrad, et lavt socialt funktionsniveau og derved et stort behov for pleje, behandling og social støtte:

De fleste af patienterne i populationen har en omfattende erfaring med det psykiatriske system og kun $5 \%$ har ikke været i kontakt med det psykiatriske behandlingssystem før indeksdom. Der er visse forskelle mellem de tre profiler: Lidt flere af debutanterne har ikke tidligere været indlagt på et psykiatrisk hospital, men en meget stor andel har været indlagt på psykiatrisk hospital 5 gange eller mere. Det gælder 4 af 10 af debutanterne, 5 af 10 af mellemgruppen, og 6 af 10 af dem med en tung profil.

De fleste har modtaget psykofarmakologisk behandling på et eller andet tidspunkt tidligere $i$ livet-også debutanterne: Mere end 7 af 10 af debutanterne har modtaget psykofarmakologisk behandling på et eller andet tidspunkt i livet (før indeksdom), mens tilsvarende tal er 9 af 10 for mellemgruppen og de tungt kriminalitetsbelastede.

Stor variation $i$ alder ved første kontakt til det psykiatriske system - fra 0 til 52 år: Debutanterne var i gennemsnit 29,3 år ved første kontakt til det psykiatriske system (median er 27 år), mens gennemsnitsalderen er i overkanten af 23 år for patienterne med en mellemprofil og de med en tung profil (median henholdsvis 23 og 22 år) $(\mathrm{p}=0,007)$.

Alvorlige psykiatriske diagnoser: 8 af 10, der er henvist til behandling i det specialiserede retspsykiatriske team, er diagnosticeret med en diagnose i skizofrenispekteret, hyppigst paranoid skizofreni. 


\section{Kriminalitetshistorik: indekskriminalitet \& tidligere kriminalitet}

For at få et overblik over patientpopulationens »modus operandi« er det nødvendigt at kende den samlede kriminalitetsportefølje, der inkluderer indekskriminalitet $o g$ tidligere kriminalitet. Størstedelen af populationen er tidligere dømt for kriminalitet. I det følgende ser vi først på indekskriminaliteten, der ligger til grund for det aktuelle behandlingsforløb, og derefter på den samlede kriminalitetshistorik.

\subsection{Indekskriminalitet: forskelle \& ligheder mellem profilerne}

Indeksdomme - hvilke domstyper ligger til grund for behandlingsforløbet: Størstedelen af populationen, $74 \%$, er dømt til psykiatrisk behandling med mulighed for indlæggelse på psykiatrisk hospital (»behandlingsdom«). $19 \%$ er i udgangspunktet idømt en anbringelse på psykiatrisk hospital, ${ }^{31}$ som er den mest indgribende psykiatriske særforanstaltning, man kan idømmes. I underkanten af $10 \%$ er idømt en »ambulant behandlingsdom« med mulighed for, at overlægen, som regel i samråd med Kriminalforsorgen, kan beslutte, at patienten skal indlægges på psykiatrisk afdeling.

Domstyperne fordeler sig ulige mellem de forskellige profiler: Hele $25 \%$ af debutanterne er idømt en anbringelsesdom, mens det gælder ca. $12 \%$ af mellemgruppen og $10 \%$ af dem, der er mest kriminalitetsbelastede. Behandlingsdommene fordeler sig mere lige: Ca. $80 \%$ af mellemgruppen og de mest kriminalitetsbelastede er i indeksdom idømt en behandlingsdom, og det samme er $56 \%$ af debutanterne.

Indekskriminalitet - variation $i$ antal forhold: De 172 patienter er i indeksdommene dømt for i alt 886 kriminelle forhold. Mængden af forhold i indeksdommene følger mønsteret i profilerne for den samlede mængde kriminalitet, patienterne er dømt for i deres hidtidige livsløb: Debutanterne er i indeksdom i gennemsnit dømt for 3,4 forhold, mellemgruppen for 4,2 forhold og de tungt kriminalitetsbelastede er i indeksdommen i gennemsnit dømt for 6,8 forhold.

De fleste er i indeksdom dømt for personfarlig kriminalitet, men mange er også $i$ indeksdom dømt for andre lovbrudstyper: Fælles for de tre kriminalitetsprofiler er, at de fleste er dømt for personfarlig kriminalitet ${ }^{32} \mathrm{i}$ indeksdommen, ${ }^{33}$ men der er markante forskelle mellem profilerne med hensyn til, hvorvidt også ikkepersonfarlig kriminalitet indgår i dommen $(\mathrm{p}=0,005)$ :

- Personfarlig kriminalitet indgår (evt. sammen med andre lovbrudstyper) i indeksdommen for $94 \%$ af debutanterne, $90 \%$ af mellemgruppen og for $76 \%$ af dem med en tung kriminalitetsprofil. Nogle af disse er i indeksdom dømt 
for kun at have begået personfarlig kriminalitet. Det gælder $66 \%$ af debutanterne, $54 \%$ fra mellemgruppen og kun $26 \%$ af de tungt kriminalitetsbelastede.

Den type personfarlige kriminalitet, der er begået af de største andele af profilerne, er vold eller trusler mod offentligt ansatte, vold i øvrigt og røveri. Vold og trusler mod offentligt ansatte er begået af ca. $35 \%$ af patienterne i hver profil. Vold i øvrigt er begåete af $25 \%$ af debutanterne, $46 \%$ fra mellemgruppen og $30 \%$ af dem med tung profil. Røveri indgår i indeksdom for $27 \%$ af dem med tung profil, og i $13 \%$ af de to andre profiler. $25 \%$ af debutanterne (8 personer) er dømt for drab eller drabsforsøg, mens det gælder for 2 fra mellemgruppen men ingen af dem med tung profil. I alt 14 personer er dømt for ildspåsættelse (fordelt på profilerne er det henholdsvis 4,8 og 2 personer). Ingen af debutanterne er dømt for voldtægt eller voldtægtsforsøg, mens det gælder for 4 personer i mellemgruppen og 5 personer med tung profil. For de fleste ofre for den personfarlige kriminalitet, der omfattes af denne undersøgelse, er den fysiske skadegrad moderat eller lille.

Den personfarlige kriminalitet er central og omfatter de fleste i populationen, men det er interessant og væsentligt, hvor meget andre former for kriminalitet fylder i indeksdommene og hvor mange, der også er dømt for både personfarlig og ikkepersonfarlig kriminalitet. Det gælder $51 \%$ af de tungt belastede, $36 \%$ af mellemgruppen og $28 \%$ af debutanterne.

- Den ikke-personfarlige kriminalitet i indeksdommene:

Berigelseskriminalitet og brud på lov om euforiserende stoffer er de ikkepersonfarlige lovbrudstyper, der fylder mest: $44 \%$ af de tungt kriminalitetsbelastede er i indeksdom dømt for berigelseskriminalitet som tyveri, omgang med hittegods eller brugstyveri. Det samme er $22 \%$ fra mellemgruppen og 9 $\%$ af debutanterne. En tredjedel af dem med en tung kriminalitetsprofil er i indeksdom dømt for brud på lov om euforiserende stoffer, mens det kun gælder en lille andel af de andre grupper (kun 4 personer tilsammen). Derimod er få personer dømt for grov narkotikakriminalitet i indeksdommen (tilsammen 5 personer). Mange er dømt for færdselslovovertrædelser. Det gælder $13 \%$ af de tungt belastede og næsten $9 \%$ fra mellemgruppen. Næsten $8 \%$ af den samlede population er i indeksdom også dømt for hærværk, $14 \%$ er dømt i kategorien »straffeloven i øvrigt«, og hele $25 \%$ er dømt for lovbrud i kategorien »særlovgivningen i øvrigt« (typisk besiddelse af kniv med ulovlig størrelse e.1.). 
- For en del omfatter indeksdom kun ikke-personfarlig kriminalitet. Det gælder $23 \%$ af de tungt kriminalitetsbelastede og henholdsvis $9 \%$ og $6 \%$ af mellemgruppen og debutanterne.

Vi ser altså i indeksdommene store variationer i både antal forhold og type forhold, patienterne er dømt for. Særligt markant (og signifikant) er forskellene mellem profilerne i forhold til hvorvidt, og i hvilket omfang, personfarlig kriminalitet indgår i deres indeksdom. Det er også bemærkelsesværdigt, hvor meget den ikkepersonfarlige kriminalitet fylder, både i forhold til mangfoldighed og omfang.

Lad os nu se på den samlede kriminalitetshistorik.

\subsection{Den samlede kriminalitetsportefølje: markante forskelle mellem profilerne}

En grundantagelse i denne undersøgelse er nødvendigheden af at kende den samlede kriminalitetshistorik og hvilke kriminelle handlinger, der hidtil har indgået $\mathrm{i}$ den enkeltes kriminalitetsprofil, og følgelig hvilke kriminelle handlinger man skal være særlig opmærksom på i forhold til eventuelt recidiv til ny kriminalitet. Vi ser først på alder for kriminel debut:

Ung kriminalitetsdebut \& tung belastningsgrad - stor forskel $i$ alder for kriminel debut: Samlet er 8 af 10 tidligere (før indeksdom) dømt for at have begået kriminalitet, men der er store forskelle mellem profilerne i forhold til, hvor gamle de var ved deres kriminelle debut: De tungt kriminalitetsbelastede var i gennemsnit 20,5 år, mellemgruppen 23,3 år, mens debutanterne var hele 36,8 år (medianen er henholdsvis 17, 21 og 34 år).

Forskellene mellem profilerne tydeliggøres yderligere ved at se på, hvor mange der kriminalitesdebuterer før det fyldte 25. år: Det gør mere end 8 af 10 af de tungt kriminalitesbelastede, 6 af 10 fra mellemgruppen, men kun lidt flere end 1 af 10 af debutanterne $(p=0,0001)$. En logistisk regression viser, at der er 25 gange større sandsynlighed for, at en med tung kriminalitetsprofil har haft en kriminel debut før det 25 . leveår i forhold til en patient i debutantgruppen, og for en fra mellemgruppen er sandsynligheden 9 gange større.

Tidligere kriminalitet og tidligere domstype: 140 patienter i populationen er tidligere dømt, og $93 \%$ af disse er tidligere idømt en psykiatrisk særforanstaltning. Mange er også tidligere idømt andre sanktioner, herunder fængselsstraffe, men $24 \%$ af populationen er tidligere idømt kun psykiatriske særforanstaltninger. ${ }^{34}$ Samlet er de 140 tidligere dømt for at have begået minimum 2455 kriminelle forhold. ${ }^{35}$

Personfarlig kriminalitet indgår i domsgrundlaget for størsteparten af de med en kriminel fortid, og omfatter $92 \%$ af de med en tung kriminalitetsprofil og 77 
$\%$ af mellemgruppen. De lovbrudskategorier, de største andele af dem der har en tidligere kriminalitetserfaring tidligere er dømt for at have overtrådt, er »vold i øvrigt« (omfatter henholdsvis næsten 7 af 10 og 4 af 10), vold og trusler mod offentlig ansatte (omfatter henholdsvis 6 af 10 og 3 af 10) og røverier (omfatter henholdsvis 6 af 10 og 2 af 10).

Den personfarlige kriminalitet fylder i den tidligere kriminalitetsportefølje, men det gør de fleste andre lovbrudstyper også. Tyverier ${ }^{36}$ er den lovbrudstype der, udover den personfarlige kriminalitet, er begået af de største andele af de der har en tidligere kriminalitetserfaring. Næsten 9 af 10 af de tungt belastede og 6 af 10 fra mellemgruppen er tidligere dømt for tyveri (med henholdsvis $15 \mathrm{og}$ ca. 3 forhold i gennemsnit), og mange er også dømt for at have overtrådt Lov om euforiserende stoffer (henholdsvis 7 af 10 og 2 af 10) og for at have overtrådt færdselslovgivningen (henholdsvis 6 af 10 og 2 af 10).

\subsection{Samlet kriminalitetsportefølje - tidligere \& indekskriminalitet}

Ser vi på den samlede kriminalitetsportefølje, dvs. både tidligere kriminalitet $o g$ indekskriminalitet, forstærkes mønsteret fra vores gennemgang af indekskriminaliteten. De fleste af dem, der også tidligere er dømt, har en blandet lovbrudsprofil bestående af både personfarlig og ikke-personfarlig kriminalitet. Det gælder $87 \%$ fra mellemgruppen og $96 \%$ af de med en tungt belastet profil. Kun 3 personer fra disse grupperne er aldrig dømt for at have begået personfarlig kriminalitet. Samlet set er kun 1 person $(1,4 \%)$ med tung profil kun dømt for personfarlig kriminalitet og tilsvarende er $12 \%$ af mellemgruppen. Debutanternes samlede kriminalitetsportefølje er den samme som beskrevet i afsnittet om indekskriminalitet, dvs. $66 \%$ af debutanterne er kun dømt for personfarlig kriminalitet, mens $28 \%$ er dømt for både personfarlig og ikke-personfarlig kriminalitet.

Dem, der begår mest kriminalitet, begår også flest type lovbrud: Analysen af den samlede mængde og type kriminalitet viser altså, at de med en tung kriminalitetsprofil (baseret på en analyse af kriminalitetsaktivitet), også er dem, der i størst grad har begået både personfarlig og ikke-personfarlig kriminalitet. Mellemgruppens samlede kriminalitetsportefølje ligner den tunge profils, mens debutanters profil er markant anderledes og i større grad præget af kun personfarlig kriminalitet.

Ny kriminalitet $i$ behandlingsforløbet: Undersøgelsens formål er ikke at vurdere den kriminalitetsforebyggende effekt af behandlingsdommen i forhold til recidiv eller den konkrete behandling, der gives i det specialiserede team. Det er alligevel interessant at se på forekomsten af ny kriminalitet i løbet af de behandlingsforløb, der er afsluttet. ${ }^{37} 27$ patienter er idømt i alt 35 nye domme i løbet af be- 
handlingsforløbet. 9 af disse patienter blev idømt nye behandlingsdomme, hvilket indebar, at det igangværende behandlingsforløb i det specialiserede team 'blot' blev forlænget. 12 blev idømt en anbringelse på psykiatrisk hospital, hvilket indebærer, at patienten skal opholde sig i et psykiatrisk hospital, indtil domstolen ændrer dommen til en behandlingsdom, hvorefter den idømte psykiatriske behandling med tiden kan varetages ambulant. 6 personer blev i forbindelse med de nye tiltaler nu fundet strafegnet og idømt ubetinget fængsel. Den nye pådømte kriminalitet omfatter tilsammen ca. 180 forhold, hvoraf 35 karakteriseres som personfarlig kriminalitet, 40 er tyveri og anden berigelseskriminalitet, 19 er brud på færdselslovgivningen, 20 omhandler euforiserende stoffer, 5 tilfælde er hærværk, og de øvrige er typisk ulovlig besiddelse af våben (kniv). Yderligere har 7 patienter modtaget $\mathrm{i}$ alt 29 tiltalefrafald ${ }^{38}$ for meget forskellige type lovbrud: $\mathrm{fx}$ fra enkelttilfælde af vold til 50 tyverier (det sidste udløste dog i alt 6 tiltalefrafald til samme person). Variationen er stor, men mønsteret for recidiv i behandlingsforløbet er det samme som for tidligere kriminalitet og indekskriminalitet: De patienter, der i udgangspunktet er mest kriminalitetsbelastede, begår i større grad end patienter med de to andre profiler ny kriminalitet i løbet af behandlingsforløbet. Det omfatter 44,2 \% af 'de tunge', 23,5\% fra mellemgruppen og kun 4,3\% ( 1 person) fra debutanterne $(\mathrm{p}=0,003)$.

Forskellen i recidiv i behandlingsforløbet genfindes ikke i indlæggelsesfrekvens på psykiatrisk afdeling i løbet af det ambulante behandlingsforløb: Ca. 8 af 10 patienter har været indlagt på psykiatrisk afdeling i løbet af behandlingsforløbet, og der er ingen signifikant forskel mellem profilerne. Statistiske analyser foretaget ved logistisk regression viser også, at det eneste signifikante parameter for recidiv under behandlingsforløbet i teamet er at patienten er tilhørende gruppen med en 'tung kriminalitetsprofil': Sandsynligheden for at en patient med tung kriminalitetsprofil begår ny kriminalitet i løbet af behandlingsforløbet er 15 (OR $=14,54$ ) gange højere end for en debutant.

\section{Opsummering af resultater: kompleksitet \& diversitet}

Patientpopulationens kompleksitetsgrad er påfaldende og omfattende, og tilsvarende er populationens heterogenitet og diversitet. Der er stor variation i omfang af patienternes tidligere erfaringer med det psykiatriske system og stor variation $\mathrm{i}$ omfang af og type tidligere kriminalitet, samt hvilke strafferetslige sanktioner de eventuelt tidligere er idømt.

Et gennemgående og fælles træk er dog omfanget af risikofaktorer, der er på spil i patienternes liv i tillæg til alvorlig psykisk sygdom. Vores analyse har vist, at en meget stor andel af populationen har oplevet alvorlige omsorgssvigt under 
opvæksten. Selvom der er forsøgt grebet ind i forhold til vanrøgt eller overgreb, fx ved anbringelse udenfor hjemmet, er det velkendt $\mathrm{i}$ anden socialforskning, at denne gruppe forbliver udsat og bærer mange problemer og sårbarheder med videre i voksenlivet. ${ }^{39}$ Det er ligeledes velundersøgt, at børn og unge, der udsættes for fysisk eller psykisk vold, kan få langvarige mén og at det kan have indgribende konsekvenser for deres kognitive, sociale og følelsesmæssige udvikling, deres generelle trivsel og mentale helbred. ${ }^{40}$ Mangelfuld skolegang, omsorgssvigt, misrøgt og begrænsede kognitive færdigheder/eller ringe empati er velkendte kriminogene faktorer. ${ }^{41}$ Mange har et komplicerende brug af rusmidler, og få har et aktivt forhold til arbejdsliv, familieliv eller fritidsaktiviteter. I den kliniske praksis og i mødet med den enkelte patient er der således en lang række risikofaktorer at forholde sig til og en stor opgave med at forsøge at understøtte og forstærke beskyttende faktorer.

Populationen er samlet set svært socialt marginaliseret, men belastningsgraden synes at følge de tre profiler med afsæt i kriminalitetsomfang: De tungt kriminalitetsbelastede har i højere grad end mellemgruppen og debutanterne været anbragt udenfor hjemmet i løbet af opvæksten; de har i mindre grad gennemført et grundskoleforløb; de har et højere forbrug af euforiserende stoffer; og de har i større grad en etnisk minoritetsbaggrund.

Den personfarlige kriminalitet er central i alle tre profilers kriminalitetsportefølje, men et fælles træk er bredden i kriminalitetstyper og omfanget af den ikkepersonfarlige kriminalitet, især for de tungt kriminalitetsbelastede. De tungt belastede er gennemgående yngre ved deres kriminalitetsdebut og ved deres første kontakt til det psykiatriske system - men fælles for de tungt belastede og mellemgruppen er, at de i større grad debuterer med kriminalitet (vurderet ud fra alder ved kriminalitetsdebut) og sidenhen kommer i kontakt med det psykiatriske system (vurderet ud fra alder for første kontakt). For dem, der i denne analyse er omtalt som »debutanterne«, er det modsat: Her kommer kontakten med det psykiatriske system først og kriminalitetsdebuten sker flere år senere.

Der synes dermed at være to hovedlinjer i denne population: debutanterne og de kriminalitetserfarne. Debutanterne har en omfattende sygdomshistorik, en sen kriminalitetsdebut og en »smallere« kriminalitetsportefølje med overvejende personfarlig kriminalitet. De kriminalitetserfarne - de med en tung kriminalitetsprofil og mellemgruppen - har også en omfattende sygdomshistorik, men har i højere grad debuteret med kriminalitet før de kommer i kontakt med det psykiatriske system. Der er væsentlige nuancer mellem de to undergrupper med tidligere kriminalitetserfaring, men gennemgående har de en langt bredere og mere omfangs- 
rig kriminalitetsportefølje end debutanterne, både i forhold til den samlede kriminalitetshistorik og i forhold til indekskriminalitet.

Fælles for den sammensatte, komplekse og heterogene patientpopulation er, at de er idømt en psykiatrisk særforanstaltning, hvis formål er at forebygge ny kriminalitet. Denne opgave ser ud til at medføre mange udfordringer for det psykiatriske system og aktualiserer en række spørgsmål og perspektiver.

\section{Diskussion og perspektivering}

\subsection{En omfattende og overtaget opgave}

De foregående analyser af patientpopulationen har vist, hvorledes den er belastet og udsat som følge af psykiatriske lidelser og social marginalisering, og at der er stor bredde i kriminalitetsporteføljen. Når patienten modtager en (ny) dom til behandling skal behandlingspsykiatrien således typisk agere i forhold til problemstillinger og udfordringer, der er stået på over et vist tidsrum - i nogle forløb siden den tidlige barndom og som også typisk har været, eller været forsøgt, håndteret i forskellige sektorer og af forskellige professioner: socialvæsen, kriminalforsorg, men også ofte af psykiatrien selv.

Det er ikke ærindet her at tage stilling til, hvorvidt disse problemstillinger er håndteret rettidigt eller tilstrækkeligt, men at tydeliggøre, at de problemstillinger, behandlingspsykiatrien og den behandlingsansvarlige overlæge skal arbejde med, som oftest ikke bliver mindre komplekse af at have stået på over lang tid og i store perioder af patientens liv.

\subsection{En udfordrende opgave}

Hvordan arbejder psykiatrien så med kriminalitetsforebyggelse og med at indfri formålet med en psykiatrisk særforanstaltning og ansvaret for »at forebygge yderligere lovovertrædelser«? Baseret på klinisk erfaring, deltagerobservation og uformelle samtaler med plejepersonale og behandlingsansvarlige psykiatere på tværs af såvel almenpsykiatri og specialiseret retspsykiatri, vil et umiddelbart bud på et svar være, at behandlingsdommens kriminalitetsforebyggende sigte ikke altid er lige klart, og at de tiltag og sygeplejehandlinger, der arbejdes med, typisk ikke italesættes som kriminalitetsforebyggelse. Det kan der være en række faglige og organisatoriske grunde til.

\subsection{Sygdom og kriminalitet-mødet mellem psykiatri og jura}

Det er et grundlæggende princip i dansk retspleje, at der ikke skal argumenteres nærmere for en specifik psykologisk årsagssammenhæng mellem en psykisk lidelse og en kriminel handling. Dansk ret er således ikke baseret på de såkaldte 
McNaughton Rules og princippet om »not guilty by reason of insanity«. Der opereres heller ikke med principper om partiel psykose/sindssygdom. ${ }^{42}$ Der tages i mentalundersøgelsen stilling til, hvorvidt den tiltalte vurderes at have været sindssyg eller i en tilstand ligestillet hermed på gerningstidspunktet. Hvorvidt den tiltalte vurderes at have været utilregnelig som følge af denne tilstand, og derfor skal være straffri, er et juridisk spørgsmål og afgøres af dommeren i retten. Den typiske praksis er, at retten følger mentalerklæringens konklusion, hvis psykiateren har fundet den tiltalte sindssyg og således i overensstemmelse hermed anses som utilregnelig og dermed omfattet af strfl. $\S 16 .{ }^{43}$

Hermed vil den dømte være straffri, og dommeren vil som udgangspunkt derefter beslutte en særforanstaltning (»behandlingsdom«) til forebyggelse af ny (ligeartet) kriminalitet. Det er uhyre sjældent i dansk retspraksis, at dommeren finder en sindssyg person tilregnelig, og endnu sjældnere at der ikke idømmes en særforanstaltning. Denne er ikke et alternativ til straf (selvom den ofte opfattes eller forveksles hermed) - personen er jo straffri - men derimod en fremadrettet foranstaltning, som udelukkende har et behandlings- og rehabiliteringssigte.

Det juridiske grundlag og det fraværende krav om en direkte årsagssammenhæng mellem de konkrete handlinger og den psykiske tilstand på gerningstidspunktet kan være medvirkende til, at kriminalitet ikke gives så stor opmærksomhed i behandlingsforløbet og i varetagelsen af foranstaltningen. Psykiatriens grundforståelse synes at være, at kriminaliteten er begået qua den retspsykiatriske patients psykiske sygdom, og at den kriminalitet, der begås, typisk vil være voldshandlinger og personfarlig kriminalitet som følge af den psykiske tilstand og en ofte udadreagerende adfærd. For denne »klassiske retspsykiatriske patient « vil opgaven for psykiatrien logisk nok være at give en adækvat psykiatrisk behandling.

\subsection{Det organisatoriske grundlag - et ekspertområde og ikke et speciale}

En anden medvirkende forklaring er, at det i psykiatriske lærebøger og i beskrivelser af retspsykiatrisk praksis har været et klassisk mantra, at der ikke findes nogen særlig retspsykiatrisk behandling, men at patienter med retslige foranstaltninger skal tilbydes »almindelig god psykiatrisk behandling «. ${ }^{44}$

Mantraet hænger formentlig sammen med, at retspsykiatri i en dansk sammenhæng ikke er et specialområde eller et subspeciale, men et »ekspertområde«. Det er ofte fremhævet, at de retslige patienters psykopatologi og diagnoser ikke adskiller sig fra resten af den psykiatriske population, og at de derfor har behov for den samme slags psykiatriske pleje og behandling som alle andre psykiatriske patienter. ${ }^{45}$ I forlængelse heraf betones det dog, at retspsykiatriske patienter ad- 
skiller sig ved deres retslige status og, i mange forløb, ved en højere kompleksitetsgrad. ${ }^{46}$

I slutningen af 1980erne kom der fokus på, at der måske alligevel var behov for særligt specialiserede afdelinger for de mest komplekse retslige patienter. Det første specialiserede retspsykiatriske afsnit blev etableret på Sct. Hans Hospital i $1989,{ }^{47}$ og siden er antallet af specialiserede retspsykiatriske sengepladser øget, mens antallet af almenpsykiatriske senge er reduceret. ${ }^{48}$ Denne øgede specialisering udfordrer princippet om, at der ikke er tale om nogen særlig retspsykiatrisk behandling. Det samme gør den aktuelle internationale debat om, hvorvidt det er meningsfuldt at skelne mellem psykiatrisk sygepleje og retspsykiatrisk sygepleje. ${ }^{49}$ På trods af den øgede specialisering bliver flertallet af patienter med retslige foranstaltninger i Danmark fortsat behandlet i almenpsykiatrisk regi og de allerfleste ambulant. Den politiske udmelding på området er fortsat, at størstedelen af den retspsykiatriske population i Danmark kan og skal tilbydes pleje og behandling i almenpsykiatrisk regi. Kun de mest komplekse og/eller farlige patienter vurderes at høre hjemme i den specialiserede retspsykiatri. ${ }^{50}$

\subsection{Er tale sølv og tavshed guld, når det drejer sig om de kriminelle handlinger?}

En anden forklaring på, at psykiatriens arbejde med kriminalitetsforebyggelse ikke fremstår så tydeligt, kan være forskellige holdninger til, hvordan og hvorvidt man taler med patienterne om den kriminalitet, de har begået. Nogle patienter kan være svært præget af skyldfølelse over det pådømte, og det kan derfor være tabubelagt og vanskeligt at bringe op i en samtale. Nogle personalemedlemmer kan mere eller mindre bevidst reagere med afstandstagen eller moralsk fordømmelse $i$ forhold til en specifik kriminel handling og derfor opleve, at det er vanskeligt at samtale med patienterne om det. Relationen mellem det behandlende personale og patient er central, og der kan også være en opfattelse blandt personalet om, at for meget snak eller for detaljeret kendskab til patientens kriminalitetshistorik, især hvis det vedrører meget personfarlig kriminalitet, kan gøre det vanskeligt at etablere en positiv relation til patienten. Tavshed om og manglende fokus på de konkrete kriminelle handlinger, der er begået, begrundes også tit med ønsket om at »fokusere på mennesket, og ikke på handlingerne«, og opfattelse af at psykiatriens opgave er at »behandle den sygdom, som menes at ligge bag kriminaliteten, men ikke kriminaliteten selv «. ${ }^{51}$

Vi ved ikke, hvorledes personalets syn på patienternes kriminalitet influerer på det professionelle arbejde, men en kortlægning af udviklingstendenser i dansk retspsykiatri fra 2011 pegede dog på en øget tendens til, at personalet ser krimina- 
liteten som en selvstændig og bevidst handling og ser mindre på sammenhængen mellem sygdom og kriminalitet. ${ }^{52}$ Det vil sige, at der måske generelt både i samfundet, i den offentlige debat og muligvis også blandt social- og sundhedsprofessionelle er mindre forståelse for sammenhængen og sammenfald mellem patienters kriminalitet og deres psykiske sygdom. ${ }^{53}$ Fokuseringen på kriminalitet indebærer således også en risiko for at bidrage til stigmatisering af en allerede udsat gruppe, der både har en psykisk sygdom og har begået kriminalitet. Derved kan der komme mere fokus på denne gruppe patienter som »kriminelle« fremfor at se dem som patienter i sundhedsvæsenet, med samme ret til pleje og behandling som alle andre borgere. ${ }^{54}$ På den anden side kan det være svært at forebygge ny kriminalitet, hvis man ikke er opmærksom på den enkelte patients »modus operandi« og kriminalitetshistorik.

\subsection{Hvilken type kriminalitet og hvilken type kriminalprcevention?}

En meget oplagt forklaring på, hvorfor det kriminalitetsforebyggende arbejde måske ikke er så eksplicit i den psykiatriske praksis, er moengden af og variationen i type af lovbrud, som det er dokumenteret i de foregående analyser, og at dette komplicerer opgaven.

Når det gælder personfarlig kriminalitet som vold og trusler, udadreagerende adfærd osv., der kan være tæt forbundet med en sindssygelig/psykotisk tilstand, er psykiatriens mest oplagte og effektfulde redskab at behandle den psykotiske tilstand for derved at mindske en uhensigtsmæssig eller farlig adfærd samt risikoen for at patienten gør skade på andre. I forhold til denne kriminalitetsform har psykiatrien konkrete redskaber til vurdering af risiko for ny voldskriminalitet, og både HCR-20 og Brøset Violence Check-list ${ }^{55}$ anvendes i dansk psykiatri.

Men det kan være vanskeligere at pege på, hvad man skal stille op i forhold til andre typer af kriminalitet, der for en umiddelbar betragtning synes mere rationelle og derfor vanskeligere at forstå i lyset af sygdom; fx gentagne brugstyverier, handel med euforiserende stoffer, overtrædelser af færdselslov (fart, køre uden kørekort osv.). Når kriminaliteten ikke er direkte afledt af en psykotisk tilstand, der eventuelt kan behandles medikamentelt, kan den psykiatriske indsats ofte komme til kort. Det kriminalitetsforebyggende arbejde vil her i højere grad skulle kredse om generelt at mindske risikofaktorer og at styrke beskyttende faktorer i det miljø, patienten lever og færdes i.

Ser man nærmere på praksis i de specialiserede retspsykiatriske teams, der varetager ambulant behandling af de mest komplekse retslige patienter, er det karakteristisk, at der arbejdes med mange typer tiltag. For mange patienter er fastholdelse i medikamentel behandling et centralt element. Men sideløbende hermed 
foregår en række sygeplejehandlinger og miljøterapeutiske tiltag: tiltag der understøtter patientens netværk/kontakt til familie og pårørende; social færdighedstræning; træning i Almindelig Daglig Levevis (ADL); social støtte; sikring af bolig/indtægtsgrundlag; deeskalering af konflikter med naboer eller lokalmiljø; motivering til reduktion af brugen af legale/illegale stoffer og en mindre risikofyldt stofbrug (»harm reduction«) foruden forskellige vurderinger af risiko for vold og aggression. ${ }^{56}$ Disse teams har typisk indgående kendskab til patientens psykopatologi, tidligere forløb samt erfaringer med og respons på psykofarmakologisk behandling. Derudover giver den assertive tilgang mulighed for at observere tidlige tegn og signaler på forværring af patientens tilstand, selv om patienten er $\mathrm{i}$ ambulant behandling.

Disse tiltag benævnes ikke typisk som kriminalitetsforebyggelse, men er indsatser, der kan bidrage til at bedre patientens funktion, styrke de beskyttende faktorer i patientens miljø og dermed mindske risikoen for ny kriminalitet. En række sygeplejehandlinger har et rehabiliterende sigte, og som sådan er de også kriminalitetsforebyggende, selvom de ikke italesættes sådan i den daglige kliniske praksis. ${ }^{57}$ Nogle af disse tiltag kan være vanskelige at iværksætte og fastholde i et behandlingsforløb i den almindelige distriktspsykiatri, hvor caseload, dvs. antal patienter pr. behandler/kontaktperson, er større, og der er mindre fokus på og mulighed for en assertiv, vedholdende indsats overfor patienten. Den gennemsnitlige indlæggelsestid for almenpsykiatriske patienter er faldet støt gennem de seneste 10-20 år, og det kan have betydning for, hvad der kendetegner »god psykiatrisk behandling«, og hvor denne skal foregå. Selv om retspsykiatriske patienter kan have længerevarende indlæggelser, vil en stor del af deres behandlingsforløb typisk skulle varetages ambulant i almenpsykiatrisk regi. Det stiller store krav til viden om, hvori opgaven består og hvordan man løfter ansvaret for at forebygge recidiv til kriminalitet.

Det ultimative og mest indgribende kriminalitetsforebyggende redskab, psykiatrien har til sin rådighed, er indlæggelse på en lukket psykiatrisk afdeling i henhold til dom, dvs. frihedsberøvelse og inkapacitering. Risikoen for ny kriminalitet mindskes så længe en patient holdes afsondret fra det omgivende samfund. Indikationen for indlæggelse i henhold til dom er bredt formuleret i vejledningen fra Sundhedsstyrelsen, og en mistanke om kriminelt recidiv er tilstrækkelig: »Indikation for genindlæggelse kan eksempelvis være recidiv af misbrug, risiko for eller mistanke om kriminelt recidiv, at patienten er ophørt med at tage sin medicin, eller at patientens psykiske tilstand er forværret $^{58}$

Det er en tilbagevendende balanceakt at finde det rette forhold mellem hensynet til den enkelte patient og hensynet til det omgivende samfund. Hvornår skal 
en patient være indlagt, og hvornår kan og skal han af hensyn til muligheden for at blive rehabiliteret og at øge mulighederne for at leve i civilsamfundet være udskrevet til ambulant opfølgning? Den del af forløbet, hvor patienten følges ambulant, stiller alt andet lige større krav og andre krav til kriminalitetsforebyggelse end i de perioder, hvor man i bogstavelig forstand kan sætte sin lid til afdelingens aflåste dør som det primære kriminalitetsforebyggende tiltag. Strukturelle forhold er også medvirkende til, at retspsykiatriske patienter, der i udgangspunktet er i et ambulant behandlingsforløb, kan opleves som udfordrende når de, ved behov for en indlæggelse, indlægges på almenpsykiatriske sengeafsnit. Personalet i almenpsykiatriske afsnit kan have svært ved at se behovet for indlæggelse af den retspsykiatriske patient, og en undersøgelse blandt plejepersonale i almenpsykiatriske sengeafsnit har vist, at det er uklart for personalet, hvori opgaven med at pleje og behandle retspsykiatriske patienter består. ${ }^{59}$ Undersøgelsens informanter havde vanskeligt ved at beskrive, hvorledes de arbejdede med rehabilitering og med at forebygge recidiv til kriminalitet. Dobbeltforpligtelsen til både pleje/behandling og kontrol, der ligger i sundhedsvæsenets forvaltning af de psykiatriske særforanstaltninger, kan fremstå som uklar og ukomfortabel og kan være forbundet med angst og utryghed hos personalet.

\subsection{En uklar opgave? - hvem gør hvad, hvornår og hvordan?}

Mange forskellige parter og sektorer er involveret i varetagelsen af en psykiatrisk særforanstaltning og $\mathrm{i}$ håndteringen af de problemstillinger, der er aktuelle for store dele af den retspsykiatriske patientpopulation. Det kan bidrage til uklarheder i de enkelte sektorer og institutioners fokus og håndtering. Dertil kommer, at det formelle ansvar varierer mellem relevante aktører.

Ansvaret for varetagelsen af behandlingsdommen påhviler formelt den behandlingsansvarlige overlæge, typisk i samarbejde med Kriminalforsorgen i Frihed (KiF), der fører tilsyn med forløbet. Denne opgave er, som vi har set ovenfor, omfattende og udfordrende, og tilsyneladende ind imellem også uklar. Kriminalforsorgen »har til opgave at være koordinerende og formidlende instans i forhold til den psykiatriske afdeling, kommunen, bostedet og statsadvokaten«, og som tilsynsmyndighed skal $\mathrm{KiF}$ »tage initiativ til at koordinere handleplaner med kommunen med henblik på at understøtte en langsigtet indsats og sikre kontinuitet i samarbejdet over for fælles klienter. ${ }^{60}$ Det ligger uden for dette studies rammer at undersøge nærmere, men gennemgange af patientforløb tyder på, at der er betydelige lokale og regionale variationer i varetagelsen af tilsynsopgaven, hvor koordinerende og formidlende tilsynsfører er og hvilke opgaver, der ivaretages af det psykiatriske behandlingssted. Der synes ligeledes at være uklarheder og 
variation i, hvori den kommunale psykosociale indsats kan og skal bestå, og hvorledes der konkret samarbejdes mellem fx bostøttemedarbejdere og kontaktpersoner i behandlingspsykiatrien, såfremt patienten har behov for social støtte, jf. Servicelovens $\S 85$ eller $\S 99 .{ }^{61}$ Kommuner er ikke lovgivningsmæssigt forpligtede i forhold til at varetage psykiatriske særforanstaltninger. ${ }^{62}$

En undersøgelse fra 2010 dokumenterede, at der, set fra Kriminalforsorgens synspunkt, var en række udfordringer i samarbejdet med behandlingspsykiatrien. Det var fx vanskeligt at få indlagt patienter; patienterne blev for hurtigt udskrevet; udskrivningen fandt sted uden at der blev givet besked til KiF; og det var svært at få kontakt til den behandlingsansvarlige læge. ${ }^{63}$

En stor andel af den undersøgte population har et omfattende misbrug af legale eller illegale stoffer. At tilbyde misbrugsbehandling er et kommunalt ansvar, bortset fra når borgeren er indlagt på et psykiatrisk hospital - da er det et regionalt anliggende. Der er store variationer i, hvorledes den regionale psykiatri arbejder med misbrugsbehandling (udover substitionsbehandling), og hvorvidt retspsykiatriske patienter, der behandles ambulant, også tilbydes en kommunal misbrugsbehandling. ${ }^{64}$

Problemer vedrørende sammenhæng, koordinering og videndeling er ligeledes velbeskrevet i en rapport fra den såkaldte »Havarikommission«, der gennemgår en række psykiatriske behandlingsforløb, som lå forud for meget alvorlige hændelser. ${ }^{65}$ Der har indenfor de sidste fire år været fem tilfælde, hvor meget syge psykiatriske patienter har begået drab på personale på socialpsykiatriske bosteder, og hvor de efterfølgende kerneårsagsanalyser atter har peget på manglende videndeling, manglende koordinering, manglende sammenhængende forløb og utilstrækkelig viden om psykopatologi og risikofaktorer som centrale elementer. Det understreger, at der fortsat er behov for afklaring af snitflader og samarbejde mellem behandlingspsykiatri, KiF og kommuner: Hvem gør hvad, hvornår og hvordan?

\section{Afslutning}

Den retspsykiatriske population er sammensat, kompleks og præget af stor diversitet. Vore analyser af en særlig belastet og belastende del af populationen bekræfter dette, og populationens samlede kriminalitetserfaring, med hensyn til dens omfang (antal forhold) og bredde (type kriminalitet), er markant. Det samme er graden af sociale belastninger og komplekse sociale problemstillinger. Vore analyser viser, at en stor andel af den undersøgte retspsykiatriske population tidligere har været idømt almindelige strafferetslige sanktioner, og at mange har tidligere fængselserfaring. Analyserne viser, at selv om den samlede belastningsgrad 
er omfattende, så er der markante forskelle og tydelige profiler i den undersøgte population. En række af disse karakteristika vedrørende den sociale belastningsgrad vil være genkendelige for klinikere og i relation til de enkelte individuelle patientforløb, men det er nyt i en dansk kontekst, at en større gruppe af patienter undersøges og beskrives samlet, fremfor på kasuistisk niveau. Den detaljerede beskrivelse udfordrer dermed også tendensen til stereotype beskrivelser i pressedækning og offentlig debat om retslige patienter, hvor der typisk fokuseres på den alvorlige personfarlige kriminalitet, og mindre på sygdomsgrad og social udsathed. Vi har dog fortsat behov for mere viden om profilerne i den samlede retspsykiatriske population, og vi har behov for en mere systematisk og konstruktiv videndeling mellem relevante aktører om, hvorledes det kriminalitetsforebyggende sigte kan varetages.

Kriminalforsorgen er en central aktør i forhold til den retspsykiatriske population, både pga. populationens omfattende tidligere fængselserfaring og pga. KiFs tilsynsopgave med de fleste behandlingsdømte. Det kan derfor synes som et paradoks, at samarbejdet mellem behandlingspsykiatrien og KiF ikke er bredere, og at videndelingen og samarbejdet om kriminalitetsforebyggende tiltag ikke er mere struktureret. De specialiserede teams' brede indsats og tilgang - de sygeplejefaglige handlinger, den sociale støtte og den lægefaglige indsats - har mange lighedspunkter med de nye kriminalitetsforebyggende principper, Kriminalforsorgen nu sigter efter at arbejde efter, både i fængslerne og overfor tilsynsklienter. Disse principper, »RNR-principperne« (Risk/risiko - Need/behov - Responsivity/modtagelighed), tager udgangspunkt $i$ en individtilpasset og struktureret indsats, og omfatter et risiko- og behovsvurderingsredskab samt en tilsynsmodel, der baseres på motiverende samtaleintervention. ${ }^{66}$ Principperne indebærer, at resocialiserende, recidivhæmmende indsatser iværksættes »med hensynstagen til hvem, hvad og hvordan «, ${ }^{67}$ og at indsatserne fokuserer på klientens kognition og adfærd. Fælles for de specialiserede, særligt opsøgende teams, og de nye principper for Kriminalforsorgens kriminalitetsforebyggende arbejde, er den individtilpassede indsats og opmærksomhed på behovet for at understøtte en bred social indsats. Det er for tidligt at sige, hvorledes Kriminalforsorgens implementering af denne nye tilgang vil fungere i praksis, men det ser det ud til, at den kriminalitetsforebyggende, individtilpassede indsats her, sammen med andre tilbud i Kriminalforsorgen, ${ }^{68}$ er mere strukturerede og specifikke end tilgange og tilbud, der gives i og fra det psykiatriske behandlingssystem.

Den undersøgte retspsykiatriske populations brede og omfattende kriminalitetsportefølje, sociale belastningsgrad og marginalisering - sammen med en udtalt sygdomsgrad - er udfordrende for psykiatriens ansvar for særforanstaltnin- 
gernes kriminalitetsforebyggende formål. Kriminalitetsforebyggende indsatser foregår altid i komplekse sociale situationer, »hvor et stort antall hendelser, faktorer og prosesser foregår samtidig, som alle i ulik grad kan innvirke på utfallet «. ${ }^{69}$ Dette er en udfordrende opgave for alle, uanset hvilken profession eller sektor, der skal løfte den. Behandlingspsykiatrien skulle måske i højere grad tydeliggøre, hvor vanskelig og kompleks en opgave dette kan være, og understrege nødvendigheden af et solidt tværfagligt og tværsektorielt samarbejde samt fleksible indsatser, der kan favne og tilpasses en kompleks, belastet og heterogen patientpopulation. Samtidig kan behandlingspsykiatrien opfordres til at give det kriminalitetsforebyggende formål et mere systematisk og vidensbaseret fokus og til at have en større opmærksomhed på nødvendigheden af at italesætte kriminalitet, kriminalitetsforståelse og kriminalitetsforebyggelse.

\section{Noter}

1. Projektet er støttet økonomisk af Justitsministeriets Forskningspulje. Projektets gennemførelse og resultater er alene forfatternes ansvar. De vurderinger og synspunkter, der fremsættes i artiklen, er forfatternes egne og deles ikke nødvendigvis af Justitsministeriet.

2. Liv Os Stølan er cand.polit. og projektleder ved Kompetencecenter for Retspsykiatri, Region Hovedstadens Psykiatri, Danmark.

3. Hans Raben er speciallæge i psykiatri og overlæge i Region Hovedstadens Psykiatri, Danmark.

4. Lis Sørensen er sygeplejerske og teamleder i Region Hovedstadens Psykiatri, Danmark.

5. Mette Brandt-Christensen er speciallæge i psykiatri, ph.d., klinikchef i Region Hovedstadens Psykiatri, Danmark, og klinisk lektor, Københavns Universitet.

6. Jette Møllerhøj er cand.mag., ph.d. og leder af Kompetencecenter for Retspsykiatri, Region Hovedstadens Psykiatri, Danmark.

7. I Sverige er der ca. 2000 patienter, der er overført til »rättspsykiatriska vården«, og i Norge er ca. 240 patienter i »tvungen psykisk helsevern « (her er de mentalt retarderede ikke medregnet) (Oslo universitetssykehus, 2016). Den årlige tilvækst i Danmark af nye domme (incidens) til psykiatrisk behandling, er nu mellem 600 og 700 (Justitsministeriets Forskningskontor 2014 og 2015; Sundheds- og Ældreministeriet 2015).

8. Straffelovens § 16. I dansk retspraksis er det almindeligt, at der typisk peges på en psykiatrisk særforanstaltning, såfremt en person er blevet mentalundersøgt og fundet omfattet af straffelovens $\S 16$. Man kan også idømmes en psykiatrisk særforanstaltning i henhold til straffelovens $\S 69$, såfremt personen på gerningstidspunktet var $\mathrm{i}$ en tilstand betinget af mangelfuld udvikling, svækkelse eller forstyrrelse af de psykiske funktioner, men udgangspunktet for sanktioner i henhold til strfl. § 69 er almindelig straf.

9. Straffelovens $\S 68$ beskriver en række psykiatriske særforanstaltninger. De mest anvendte er:

a) Dom til anbringelse på psykiatrisk afdeling 
b) Dom til psykiatrisk behandling med mulighed for indlæggelse (i reglen med en længstetid på 5 år, og ved alvorlig personfarlig kriminalitet i reglen uden længstetid) og med tilsyn af Kriminalforsorgen i Frihed $(\mathrm{KiF})$.

Behandlingsdommene varetages af det psykiatriske behandlingssystem i enten almenpsykiatrisk regi (hovedfunktion) eller i specialiseret retspsykiatri (regionsfunktion). Langt størstedelen af behandlingsdommene varetages ambulant (80-90\%). Ofte består forløbet af vekslen mellem indlæggelse og ambulant opfølgning, og der kan være kortere eller længere perioder med indlæggelse i henhold til dom, såfremt den behandlingsansvarlige overlæge og kriminalforsorgen som tilsynsmyndighed har vurderet, at der er risiko for recidiv til kriminalitet. En indlæggelse kan også være frivillig, og initieret af patienten selv, evt. i samarbejde med den behandlingsansvarlige overlæge.

10. Ministeriet for Sundhed og Forebyggelse, 2015; Ministeriet for Sundhed og Forebyggelse, 2010.

11. Dvs. forhold der enten øger eller mindsker sandsynlighed for at man begår kriminalitet.

12. Se f.eks. Clausen, 2016; Jørgensen et. al., 2012; Østergaard e.t. al. , 2015; Clausen, Djurhuus \& Kyvsgaard, 2009; Justitsministeriet, 2009.

13. Se fx Hodgins, 2008; Fazel et al., 2009.

14. Vi vil herefter anvende betegnelsen »behandlingsdomme« om de psykiatriske særforanstaltninger.

15. Se også Møllerhøj et al., 2016b.

16. Projektet er godkendt af Sundhedsstyrelsen (Sagsnr. 3-3013-330/1) og Datatilsynet (RHP2013-019).

17. I Region Hovedstadens Psykiatri er der i alt to specialiserede retspsykiatriske opsøgende teams, og tilsammen har de aktuelt behandlingsansvaret for ca. 155 af de i alt ca. 1700 retspsykiatriske patienter i regionen.

18. Fra teamets start $\mathrm{i}$ april 2006 til udgangen af 2014.

19. For 9 patienter har vi kun oplysninger om, hvilke lovbrudstyper de tidligere er dømt for, men ikke oplysninger om hvor mange forhold de er dømt for i den enkelte lovbrudskategori, og de 9 er derfor udeladt i denne artikels analyser, hvor mængden af kriminelle forhold er væsentlig.

20. Indeksdom er den dom, der ligger til grund for opstart af behandlingen i det specialiserede team.

21. Alle registreringsskemaer er udfyldt af cand. polit. Liv Os Stølan i samarbejde med overlæge Hans Raben. Dette har bidraget til en ensartet og konsistent registrering.

22. Registreringsskemaet kan rekvireres ved henvendelse til forfatterne.

23. De statistiske analyserer udført af firmaet $i 2$ minds (www.i2minds.dk).

24. Populationen er også beskrevet i Møllerhøj et al., 2016 b.

25. Populationens diversitet erfares i det daglige kliniske arbejde, og indtrykket blev forstærket af arbejdet med det detaljerede registreringsskema, hvor antal forhold, ikke blot lovbrudskategorier, blev registreret. Vi forsøgte derfor først at fange bredden i kriminaliteten vha. en »mono-«(ensartet kriminalitet) og »multi-« (mange lovbrudskategorier) analyse. »Multikriminalitet« præger de fleste patienters samlede kriminalitetshistorik i en så stor grad, at denne analytiske tilgang viste sig at være uhensigtsmæssig. 
26. For at analysere forskelle mellem de tre kriminalitetsprofiler har vi anvendt multinominal logistisk regression, hvor vi har medtaget en række forklarende variable, som vi ud fra det beskrivende materiale og statistiske tests har fundet relevante og mulige at medtage i en model.

27. I alt 7 personer modtager uddannelsesstøtte, og kun 1 person har ordinær arbejdsindkomst.

28. Gælder $73,2 \%$ fra den »tunge« profil og $68,1 \%$ fra mellemgruppen.

29. Med »etnisk minoritetsbaggrund « forstås patienter, som enten selv er født udenfor Danmark, eller hvor mindst en af forældrene er født udenfor Danmark. Størstedelen af dem med en etnisk minoritetsbaggrund har en baggrund fra ikke-vestlige lande, og de fleste er ikke født i Danmark: 71 af de i alt 88 personer med etnisk minoritetsbaggrund (af hele populationen på 181 personer) er tilflyttere, og de var i gennemsnit ca. 19 år gamle da de kom til Danmark. De fleste har, før indeksdom, levet det meste af deres liv i Danmark: $44 \%$ har levet minimum halvdelen af deres liv i Danmark; $37 \%$ har levet mellem $25 \%$ og $50 \%$ af livet i Danmark, mens $14 \%$ kun har levet under $25 \%$ af deres liv i Danmark før indeksdom.

30. De fleste har, før indeksdom, levet det meste af deres liv i Danmark: $44 \%$ har levet minimum halvdelen af deres liv i Danmark; $37 \%$ har levet mellem $25 \%$ og $50 \%$ af livet i Danmark, mens $14 \%$ har boet i Danmark i mindre end $25 \%$ af deres liv før indeksdom.

31. Domstolen ændrer en anbringelsesdom til en mindre indgribende foranstaltning, typisk en behandlingsdom med mulighed for indlæggelse, når patientens tilstand er tilstrækkelig stabiliseret.

32. »Personfarlig kriminalitet« inkluderer drab og drabsforsøg, vold, vold mod offentligt ansatte, ildspåsættelse, voldtægt, sædelighedskriminalitet og røveri. »Ikke-personfarlig kriminalitet« inkluderer narkotikalovbrud, euforiserende stoffer, tyveri og anden berigelseskriminalitet, færdselslovgivning og øvrige straffe- og særlove.

33. Og dette kan også være et af kriterierne for at blive henvist til det specialiserede opsøgende team.

34. Den samlede population, som grundundersøgelsen omfatter (hvor $n=181$, og ikke kun de 172 der indgår i de analyser der behandles i denne artikel), er idømt i alt 523 fængselsstraffe og 361 psykiatriske foranstaltningsdomme (inkl. indeksdom og evt. nye domme i behandlingsforløbet i det specialiserede team). Se også Møllerhøj et. al., 2016 b.

35. Oplysninger om kriminalitet er hentet fra domsudskrifterne, der indgår i patienternes journal. Nogle få af journalerne har manglet alle tidligere domsudskrifter, og vi har i disse tilfælde baseret registreringerne på Mentalerklæringens (der også er en del af journalen) oplysninger om, hvilke lovbrudskategorier patienten tidligere er dømt for. Mentalerklæringerne indeholder typisk ikke oplysninger om mængde forhold, kun lovbrudtype, og følgelig er dette et minimumstal.

36. Inklusiv ulovlig omgang med hittegods, hæleri samt brugstyveri.

37. Oplysninger om ny kriminalitet i behandlingsforløbet er kun registeret for de behandlingsforløb, der er afsluttede i teamet $(n=100)$.

38. Et tiltalefrafald indebærer anklagemyndigheden anser en som skyldig i det kriminelle forhold, men at der ikke bliver nogen straffesag, da patienten »allerede er idømt en strafferetlig foranstaltning (behandlingsdom)«, og at anklagemyndigheden ikke forventer, at foranstaltningen bliver ændret, hvis der rejses tiltale i sagen. 
39. Laustsen et al., 2013: De klarer sig ofte dårligt i skolen, over halvdelen får specialundervisning, og ikke mindst drengene er bagud i skoleforløbet. Anbragte og hjemgivne 15-årige er desuden psykisk sårbare. De har i højere grad end deres jævnaldrende tegn på depression, spiseforstyrrelser og selvskadende adfærd. De har også omfattende erfaring med illegale stoffer samt kriminalitet.

40. Oldrup et al., 2011.

41. Se fx Clausen, 2016 s. 5; Justitsministeriet 2009, s. 51-66.

42. Adserballe, 2000 s. 599.

43. Men, der er ind imellem sager, hvor dommeren ikke vurderer, at den sigtede var utilregnelig, typisk hvis der er tale om omfattende narkotikakriminalitet, økonomisk kriminalitet eller færdselslovsovertrædelser. Se Adserballe, 2000, s. 599, og Brandt-Christensen \& Berthelsen, 2010.

44. Kramp, Lunn \& Waaben, 1996; Region Hovedstadens Psykiatri, 2008; Region Midtjylland, 2014.

45. Kramp, Lunn \& Waaben, 1996.

46. Region Midtjylland, 2014.

47. Sct. Hans Hospital, 1991, s. 21.

48. Pr. 2016 er der ca. 2900 psykiatriske sengepladser i Danmark, hvoraf ca. 400 er specialiserede retspsykiatriske sengepladser.

49. Se fx Gildberg, 2012, og Mason, 2002.

50. Danske Regioner, 2011.

51. Citatet er hentet fra en etnografisk undersøgelse af samspillet mellem plejepersonale og patienter i dansk retspsykiatri (Jacobsen, 2006) og stemmer overens med udsagn, forfattergruppen møder i klinisk praksis.

52. Der er lavet internationale studier af personalets syn på patienternes kriminalitet, og hvilken betydning det kan få for det professionelle arbejde (Askola et al., 2016), men denne type viden savnes i en dansk kontekst.

53. Jacobsen \& Johansen, 2011.

54. Møllerhøj et al., 2016 a; Johansen \& Møllerhøj, 2016.

55. Pedersen \& Hougaard, 1997; Almvik, Woods \& Rasmussen, 2000.

56. Se f.eks. Strand, 2002; Buus, 2009; Hummelvoll, 2013.

57. Bredkjær, 2010.

58. Ministeriet for Sundhed og Forebyggelse, 2010.

59. Møllerhøj et al, 2016 a.

60. Kriminalforsorgen, 2016 a. I alt fører Kriminalforsorgen i Frihed (KiF) tilsyn med 9170 personer. Personer der er idømt en psykiatrisk særforanstaltning i medfør af Straffelovens $\S \S 68-69$ udgør $30 \%$ af alle med tilsyn af KiF (Kriminalforsorgen, 2016 b).

61. Jf. Bengtson \& Røgeskov, 2012; Social-og Indenrigsministeriet, 2015.

62. Regeringens udvalg om psykiatri, 2013 s. 134-137, s. 198-201.

63. Kramp, 2010.

64. Sundhedsstyrelsen, 2014.

65. Sundhedsstyrelsen, 2010.

66. Udgangspunktet er det canadisk udviklede risiko- og behovsvurderingsredskabet LS/RNR (Level of Service/Risk Need Responsivity), se Clausen, 2016. 
67. Clausen, 2016.

68. Fx Anger Management; kognitiv adfærdsterapi; misbrugsbehandling m.m.

69. Bjørgo, 2015, s. 260.

\section{Referencer}

Adserballe, H. (2000): 'Retspsykiatri'. I: Hemmingsen, R. et al. i Hemmingsen, R. et. al.: Klinisk psykiatri. København: Munksgaard Danmark.

Almvik, R., Woods P. \& K. Rasmussen (2000): »The brøset violence checklist: Sensitivity, specificity and interrater reliability.« Journal of Interpersonal Violence 2000 15 (12):1284.

Askola, R. et.al. (2016): 'The Therapeutic Approach to a Patient's Criminal Offense in a Forensic Mental Health Nurse-Patient Relationship - The Nurses' Perspectives.' Perspectives in Psychiatric Care 00(January), 1-11.

Bengtsson, S. \& M. Røgeskov (2012): Et liv i egen bolig. Analyse af bostøtte til borgere med sindslidelser. København: SFI - Det Nationale Forskningscenter for Velfærd.

Bredkjær, S. (2010): 'Rehabilitering ved dobbeltdiagnose og i retspsykiatrien.' I: Eplov, L.F. et. al.: Psykiatrisk \& psykosocial rehabilitering - en recoveryorienteret tilgang. København: Munksgaard Danmark.

Brandt-Christensen, M. \& A. Bertelsen (2010): 'Sindssygdomsbegrebet i straffelov og psykiatrilov', Ugeskrift for laeger 172, Nr. 17, 1274-1276.

Bjørgo, T. (2015): Forebygging av kriminalitet. Oslo: Universitetsforlaget.

Buus, N. (2009): Psykiatrisk sygepleje. København: Nyt Nordisk Forlag.

Clausen, S., M. Djurhuus \& B. Kyvsgaard (2009): Udredning til brug for Kommissionen vedrørende ungdomskriminalitet. Justitsministeriets Forskningskontor. København: Justitsministeriet.

Clausen, S. (2016): Delanalyse 1 vedrørende evaluering af RNR i Kif. Opfølgning på indførelsen af LS/RNR i KiF. København: Direktoratet for Kriminalforsorgen.

Danske Regioner (2011): Retspsykiatri. Kvalitet og sikkerhed. København: Danske Regioner.

Fazel, S. et al. (2009): »Schizophrenia and violence: systematic review and metaanalysis«. PLoS Medicine, Vol. 6/Issue 8/e1000120.

Gildberg, F.A. (2012): Reconstructing Normality - Interactional Characteristics of Forensic Mental Health Nursing. PhD Thesis. Odense: Syddansk Universitet.

Hodgins, S. (2008): »Violent behaviour among people with schizophrenia: a framework for investigations of causes, effective treatment and prevention.« Philosophical Transactions of the Royal Society B: Biological Sciences. 363 (1503) 2505-2518.

Hummelvoll, J.K. (2013): Helt - ikke stykkevis og delt. Psykiatrisk sygepleje og psykisk sundhed. København: Hans Reitzels Forlag.

Jacobsen, C.B. (2006): Paradoksal psykiatri. Etnografiske analyser af samspillet mellem plejepersonale og patienter $i$ dansk retspsykiatri. Ph.d.-afhandling. København: Københavns Universitet, Det samfundsvidenskabelige Fakultet, Institut for Antropologi.

Jacobsen, C.B. \& K.S. Johansen (2011): Udvalgte tendenser i dansk retspsykiatri. København: Dansk Sundhedsinstitut.

Johansen, K.S. \& J. Møllerhøj (2016): 'Stigma før og nu. Holdninger til psykiatriske patienter i historien.' I: Kragh, J.V. \& J. Møllerhøj (red.): Sct. Hans 1816-2016. København/Roskilde: Region Hovedstadens Psykiatri og Psykiatrisk Center Sct. Hans. 
Justitsministeriet (2009): Indsatser mod ungdomskriminalitet. Betcenkning nr. 1508. København: Justitsministeriet.

Justitsministeriets Forskningskontor (2014): Nye foranstaltningsdomme i 2013 samt forløbet af domme afsagt i 2008. København: Justitsministeriet.

Justitsministeriets Forskningskontor (2015): Nye foranstaltningsdomme i 2014 samt forløbet af domme afsagt i 2009. København: Justitsministeriet.

Jørgensen, T.T. et. al. (2012): Risikofaktorer, effektevalueringer og behandlingsprincipper. En forskningsoversigt. Materiale udarbejdet til brug for en tvarministeriel arbejdsgruppe om forebyggelse og resocialisering som led $i$ et udredningsarbejde på kriminalforsorgens område. Justitsministeriets Forskningskontor. København: Justitsministeriet.

Kramp, P., V. Lunn \& K. Waaben (1996): Retspsykiatri. København: GadJura.

Kramp, P. (2010): Klienter idømt en psykiatrisk scerforanstaltning. Samarbejdet mellem Kriminalforsorgen $i$ Frihed og psykiatrien - og noget om behandlingen af psykisk syge kriminelle. København: Direktoratet for Kriminalforsorgen.

Kriminalforsorgen (2016 a): Behandlingsdømte. (www.kriminalforsorgen.dk/Behandlingsd\% C3B8mte-84.aspx, tilgået 15. september 2016).

Kriminalforsorgen (2016 b): Statistik 2015. København: Kriminalforsorgen. (www.kriminalforsorgen.dk, tilgået 15. september 2016).

Laustsen, M. et al. (2013): Anbragte 15-åriges hverdagsliv og udfordringer. Rapport fra tredje dataindsamling af forløbsundersøgelsen af anbragte børn født i 1995. København: SFI Det Nationale Forskningscenter for Velfærd.

Mason, T (2002): 'Forensic psychiatric nursing: a literature review and thematic analysis of role tension'. Journal of Psychiatric and Mental Health Nursing, 9, 511-520.

Ministeriet for Sundhed og Forebyggelse (2015): Lov om retspsykiatrisk behandling m.v. Lov nr. 1396 af 21/12/2005 (www.retsinformation.dk, tilgået 15. september 2016).

Ministeriet for Sundhed og Forebyggelse (2010): Vejledning om behandlingsansvarlige og ledende overlagers ansvar for patienter, der er idømt en behandlingsdom eller en dom til ambulant psykiatrisk behandling. VEJ nr 9614 af 08/11/2010 (www.retsinformation.dk, tilgået 15. september 2016).

Møllerhøj, J., L.O. Stølan \& M.B. Christensen (2016 a): 'A Thorn in the Flesh? Forensic Inpatients in General Psychiatry', Perspectives in Psychiatric Care, 52, 2016, 32-39.

Møllerhøj, J. et al. (2016 b): '»Hun plejer da at kunne tåle, at jeg truer med at hente en motorsav ...«-Vold og trusler mod offentligt ansatte undersøgt i en dansk retspsykiatrisk population', Nordisk Tidsskrift for Kriminalvidenskab, nr. 2 2016, s. 182-204.

Oldrup, H. et al (2011): Vold mod børn og unge. København: SFI - Det Nationale Forskningscenter for Velfærd.

Oslo universitetssykehus (2016): Sikkerhedspsykiatri i Norge 2015. En statusundersøgelse. Oslo: Oslo Universitetssykehus, Kompetensesenter for sikkerhets-, fengsels- og rettspsykiatri.

Pedersen, L. og H. Hougaard (2005): HCR-20. Vurdering af voldsrisiko. Efter originalversion af C.D. Webster, K.S. Douglas, D. Eaves, S. Hart. Retspsykiatrisk Afdeling, Sct. Hans Hospital. Roskilde: Sct. Hans Hospital.

Regeringens udvalg om psykiatri (2013): En moderne, åben og inkluderende indsats for mennesker med psykiske lidelser. Rapport fra Regeringens udvalg om psykiatri. København: Regeringens udvalg om psykiatri. 
Region Hovedstadens Psykiatri (2008): Retspsykiatrisk rapport. København: Region Hovedstadens Psykiatri. Sundhedsfagligt Råd for Psykiatri.

Region Midtjylland (2014): Retspsykiatrisk Rapport. Revideret marts 2014. Århus: Psykiatri og Social. Region Midtjylland.

Sct. Hans Hospital (1991): Sct. Hans Hospital 1816 - 1991. Roskilde: Sct. Hans Hospital.

Social- og Indenrigsministeriet (2015): LBK nr 1284 17/11/2015 (Serviceloven) (www.retsinformation.dk, tilgået 15. september 2016).

Strand, L. (2002): Fra kaos mod samling, mestring og helhed - psykiatrisk sygepleje til psykotiske patienter. København: Gyldendal Akademisk.

Sundhedsstyrelsen (2010): Psykisk syge kriminelles forløb. København: Sundhedsstyrelsen.

Sundhedsstyrelsen (2014): Retningslinjer for udarbejdelse af koordinerende indsatsplaner. København: Sundhedsstyrelsen (https://sundhedsstyrelsen.dk/da/udgivelser/2014/retningslinjerfor-udarbejdelse-af-koordinerende-indsatsplaner, tilgået 15. september 2016).

Sundheds- og Ældreministeriet (2015): Kortlogning af Retspsykiatrien: Mulige årsager til udviklingen $i$ antallet af retspsykiatriske patienter samt viden om indsatser for denne gruppe. København: Sundheds- og Ældreministeriet, Faglig ekspertgruppe vedrørende Retspsykiatri.

Østergaard, S.V. et. al. (2015): På vej mod ungdomskriminalitet. Hvilke faktorer i barndommen gør en forskel? København: SFI - Det nationale forskningscenter for velfærd. 